\title{
QUANTITATED FLEXOR RESPONSE IN ACUTE SPINAL CORD INJURY PATIENTS
}

By M. Rivera-Dominguez, M.D., J. H. Frisbie, M.D. and A. B. Rossier, M.D. Spinal Cord Injury Service, West Roxbury Veterans Administration Hospital and the Departments. of Orthopaedic Surgery and Medicine, Harvard Medical School, Boston, Massachusetts, U.S.A.

\begin{abstract}
Flexor reflexes were compared with phasic stretch reflexes in 12 acute spinal cord injury patients with upper motor neuron lesions. Initial flexor reflex activity appeared later than initial stretch reflex activity in the majority of cases whereas maximal flexor reflexes developed at about the same time as maximal stretch reflexes. A quantitative method for evaluating flexor and stretch reflex activity at bedside is presented.
\end{abstract}

Key words: Spinal cord injuries; Spasticity; Flexor reflex; Stretch reflex.

\section{Introduction}

THE clinician customarily assesses recovery from spinal shock following spinal cord injury by two types of stretch response: either tonic (clasp knife resistance to passive range of motion) or phasic (deep tendon reflexes). The flexor response, i.e. involuntary withdrawal of a limb in response to a painful stimulus, is less commonly invoked in routine neurological examination, but has been described in experimental animals (Sherrington, I906; Marie and Foix, I912), noted in spinal cord injury patients (Kuhn, I950; Guttmann, I952), and quantitated electromyographically (Kugelberg, I948; Shahani and Young, 1971). The flexor response is most easily elicited by stimulation of the plantar aspect of the foot (Kuhn, I950), but can also be elicited by stimulation of more proximal areas, called excitatory skin areas. To characterise more fully the flexor response the proximal migration of excitatory skin areas have been compared with the development of phasic stretch responses following spinal cord injury

\section{Methods}

\section{Selection and Examination of Patients}

Twelve consecutive patients admitted to the spinal cord injury service within 4 days of injury (ten admitted the day of injury) were studied. There were eight cervical (one incomplete), four thoracic (two incomplete), and no thoraco-lumbar or lumbar lesions.

These subjects were examined systematically four times a week by the same examiner (M.R) from the time of admission until the flexor and stretch response grades, to be described, no longer increased after a minimum observation time of 3 weeks.

\section{Method of Examination}

The parameters of reflex activity tested and the grading system devised are indicated in Table $\mathrm{I}$. 
TABLE I

Parameters and grades of flexor and stretch reflex activity

\begin{tabular}{ll}
\hline Parameters & Grades \\
\hline Flexor reflex (withdrawal response) & \\
Absent & I \\
Withdrawal, stimulus at the foot & 2 \\
Withdrawal, stimulus below the knee & 3 \\
Withdrawal, stimulus above the knee & 4 \\
Phasic stretch reflex & \\
(Knee and/or ankle jerks) & I \\
Absent & 2 \\
Present & 3 \\
Hyperactive & 4 \\
Clonus & \\
\hline
\end{tabular}

Flexor reflexes were tested by pin pricks manually applied to the sole and dorsum of the foot, the anterior and posterior aspects of the leg (below the knee), and the anterior and posterior aspects of the thigh (above the knee) at a rate of 3-5 per second for a duration of about 5 seconds. Withdrawal of either lower extremity in response to stimulation of excitatory skin areas of the foot, leg, and thigh were graded 2,3 , or 4 , respectively.

Phasic stretch reflexes were tested by knee and ankle deep tendon reflexes using a soft rubber percussion hammer, tendons being struck briskly but with a consistent force. The reflex grade was 2 for minimal or 'normal' response, 3 for a sharp, strong response, and 4 for induced clonus. For each examination in a given patient the highest single reflex grade to be elicited on either side was recorded.

\section{Natural Course of Reflexes}

\section{Results}

The onset of the flexor response ( 3 to 74 days, median I7) was generally later than that of the phasic stretch response (I to 23 days, median 4) (Fig. I). In IO of 12 individual patients the flexor response followed the stretch response, in one patient the flexor response preceded the stretch response by I day, and in one patient the flexor response failed to appear. The last individual initially had an incomplete Di I motor and sensory level, had elicitable clonus of the knees and ankles on the second post injury day, exhibited progressive return of voluntary motor function with disappearance of clonus, and showed complete recovery on the eleventh post injury day.

Maximal flexor reflex appeared 5 to 106 days post-injury (median $25, N=10$ ), and developed about the same time as the maximal phasic stretch reflex which appeared 2-99 days post-injury (median 22, $N=10$ ). Maximal reflexes could not be compared in the one patient who failed to develop a flexor reflex and in one patient who was transferred to another hospital before follow-up was complete.

The evolution of the flexor and phasic stretch reflexes was variable, the time from initial to maximal flexor response being 0-103 days (median $2, N=10$ ) and 


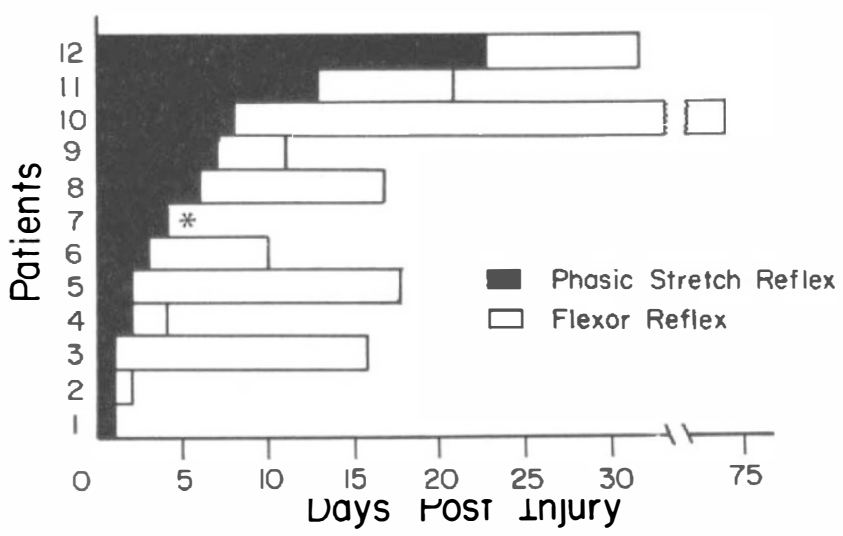

FIG. I

Onset of phasic stretch reflex $v$. flexor reflex. The solid bar represents time between spinal cord injury and initial phasic stretch reflex. The open bar represents additional time until the onset of initial flexor reflex could be elicited.

* Patient 7 was exceptional in exhibiting a flexor reflex $\mathrm{I}$ day before a phasic stretch reflex could be elicited.

the time from initial to maximal phasic stretch reflex being 0-95 days (median II, $N=$ I0).

\section{Grade of Reflexes}

The maximal flexor and phasic stretch grades correlated within I grade point for Io of I I patients. The greatest discrepancy occurred in the one patient mentioned previously who had clonus transiently but no flexor reflex, and who recovered from spinal cord trauma I I days post-injury.

\section{Discussion}

The observations that flexor reflexes often, but not always, follow the appearance of phasic stretch reflexes, that flexor reflexes quantitated by proximal migration of excitatory skin areas tend to accentuate with time, and that the more extensive flexor reflexes thus quantitated are associated with the more prominent phasic stretch reflexes agree with previous reports of flexor responses in spinal cord injury patients (Kuhn, I950; Guttmann, I952).

The repeated observations of the flexor and phasic stretch responses in this study give us a wider spectrum of both polysynaptic and monosynaptic reflexes respectively as they develop after spinal cord injury. The adoption of the most proximal excitatory skin area as a method of quantitating the flexor response offers more reliability than is available by varying the stimulus or judging the extent of reflex response. The convenience of the flexor response quantitated by the level of excitatory skin areas offers a bedside technique for correlation with other events following upper motor neuron lesions, such as flexor response and pes cavus (Rivera-Dominguez). 


\section{SUMMARY}

Flexor reflexes, graded by the degree of proximal migration of the upper level of excitatory skin areas of the lower extremities, were compared with phasic stretch reflexes, using a 4-point scoring system in 12 acute spinal cord injury patients with upper motor neuron lesions. Initial flexor reflex activity (3-74 days post-injury) developed later than initial stretch activity ( $\mathrm{I}-23$ days post-injury) in Io of I I patients, failing to appear in one patient with transient paralysis. Maximal flexor reflexes, however, developed at about the same time as maximal stretch reflexes (5-106 days v. 2-99 days post-injury, respectively) and showed little difference in intensity (O-I grade point difference for IO of I I patients). Quantitation of the flexor reflex by the proximal migration of excitatory skin areas is a convenient bedside technique for comparison with other types of reflex activity.

\section{RÉSUMÉ}

Utilisant un système de valeurs basé sur une échelle de 4 points, les auteurs comparent chez I2 lésions médullaires traumatiques aiguës du type neurone moteur supérieur les réflexes phasiques en extension avec les réflexes en flexion jaugés en function de l'importance de la migration proximale des zones cutanées excitatrices le long des membres inférieurs. Alors qu'elle faisait défaut chez un patient à paralysie transitoire, chez Io patients sur II l'apparition initiale des réflexes en flexion, 3 à 74 jours après le traumatisme, se manifesta plus tardivement que celle des réflexes en extension, I à 23 jours après le traumatisme. Par contre, la date d'apparition, après le traumatisme, de l'effet maximal des réflexes en flexion (5-106 jours) se situa à peu près au même moment que celle des réflexes en extension (2-99 jours), la difference quantitative d'intensité entre ces deux types de réflexes étant par ailleurs minime (O-I point de différence chez Io patients sur II).

Basée sur la migration proximale des zones cutanées excitatrices, la technique de quantification des réflexes en flexion semble intéressante en tant que méthode applicable au lit du patient permettant la comparion avec d'autres types d'activité réflexe.

\section{ZUSAMMENFASSUNG}

Bei 12 frischverletzten Rückenmarkgeschädigten mit Läsionen des oberen motorischen Neurons wurden nach dem Grad proximaler Migration des oberen Niveaus der Hautreizzonen auf den Beinen die Beugereflex der unteren Extremitäten mit phasischen Streckreflexen verglichen. Es wurde eine 4-Punkte Bewertung benützt. Bei Io von I I Patienten entwickelte sich die initiale Reflexaktivität der Flexoren (3-74 Tage nach der Verletzung) später als diejenige der Streckmuskeln (I-23 Tage nach der Verletzung), fehlte jedoch bei einem Patienten mit vorübergehender Lähmung. Die maximale Reflexaktivität der Flexoren entwickelte sich hingegen fast gleichzeitig wie diejenige der Streckmuskeln (5-106 Tage bzw. 2-99 Tage nach der Verletzung) und zeigte wenig Unterschied in ihrer Intensität (o-I Punkt Unterschied bein Io von I I Patienten). Das Messen des Beugereflexes durch proximale Migration von Reizzonen der Haut ist eine brauchbare Technik am Bettrand für den Vergleich mit anderen Arten der Reflexaktivität.

Acknowledgements. The authors wish to thank Professor N. Geschwind, Boston, for his help and advice in reviewing this paper.

\section{REFERENCES}

Guttmann, L. (1952). Studies on reflex activity of the isolated cord in the spinal man. 7. Nerv. Ment. Dis., 116, 957.

Guttman, L. (1976). Spinal Injuries: Comprehensive Management and Research, 2nd Edition. Blackwell Scientific Publications, Oxford.

Kugelberc, E. (1948). Demonstration of A and C fibre components in the Babinski plantar response and the pathological flexor reflex. Brain, 71, 304. 
KuHN, R. A. (1950). Functional capacity of the isolated human spinal cord. Brain, 73, I.

MArie, P. \& Forx, C. (I9I2). Les réflexes d'automatisme médullaire. Rev. Neurol., 23, 657 .

Rivera-Dominguez, M., DiBenedetto, M., Frisbie, J. H. \& Rossier, A. B. Pes cavus and claw toes deformity in patients with spinal cord injury and multiple sclerosis. Paraplegia, 16, 375.

Shahani, B. T. \& Young, R. R. (I97I). Human flexor reflexes. F. Neurol. Neurosurg. Psychiat., 34, 6I6.

Shahani, B. T. \& Young, R. R. (I97I). Management of flexor spasms with Lioresal. Arch. Phys. Med. Rehabil., 55, 465.

Sherrington, C. S. (I906). The Integrative Action of the Nervous System. Cambridge University Press, New York, reprinted 1947. 